\title{
DETERMINATION OF VOLUMETRIC CONTRACTION AND DRYING KINETICS OF THE DRYED BANANA
}

\section{Lucas Fernandes de Souza}

Fluminense Federal University, Engineering Dept., P.O. Box 121.799, ZIP Code 24210-240, Niterói-RJ, Brazil

\section{Ednilton Tavares de Andrade}

Federal University of Lavras (UFLA), Engineering Dept., P.O. Box 3037, ZIP Code 37.200-000, Lavras-MG, Brazil

\author{
Paula de Almeida Rios \\ Federal University of Lavras (UFLA), Engineering Dept., P.O. Box 3037, ZIP Code 37.200-000, Lavras-MG, Brazil \\ Corresponding author: paulariosagricola@gmail.com
}

\begin{abstract}
Banana (Musa spp.) is one of the most nutritious and consumed fruits, especially in tropical countries. The drying of the fruit is an alternative against the injuries suffered, mainly during the post-harvest process. Thus, the knowledge of the physical properties of the product that is intended to be processed has a big importance for the dimensioning of equipment. Therefore, the objective of this work was to study the drying kinetics of the banana, transforming it into dried banana, besides evaluating the volumetric contraction suffered during drying. The bananas were dried in an oven at temperatures of 70,60 and $50{ }^{\circ} \mathrm{C}$. The volumetric measurements were carried out before and after drying to determine the volumetric contraction during the process. After drying, the experimental data were modeled by nonlinear regression analysis by the Quase-Newton method, to adjust 4 mathematical models of moisture ratio and 5 mathematical models of volumetric contraction. Among the models tested, the best fit for the prediction of the Moisture Ratio was the exponential model, and for the Volumetric Contraction was the modified BALA and WOOD model.
\end{abstract}

Index terms: Musa spp., drying curves, mathematical modeling.

Received: June, 26, 2018 - Accepted: August, 16, 2018

\section{INTRODUCTION}

The banana (Musa spp.) is an edible fruit, very nutritious, because it is a source of minerals such as potassium, calcium, phosphorus, iron, magnesium, as well as vitamins, making it one of the most consumed fruits in Brazil and around the world. Banana drying process is an alternative to losses caused during the postharvest process, damages in transportation, handling and storage, as well as adding value to the product (Ribeiro, 2014).

Banana is a highly hygroscopic biological product. Hygroscopic products have the property to carry out water changes, in the form of vapor or liquid with the surrounding environment, by absorption or desorption (Lima et al., 2000).

Many researchers have used mathematical approximations and models in an attempt to better represent the phenomenon of volumetric contraction and drying kinetics in products of a biological nature.

According to Siqueira et al. (2012), the volumetric contraction index represents the ratio of the fruit volume or grain for each water content by the initial volume. This parameter has a fundamental importance in drying processes in dryers, since it allows better prediction of the behavior of the product in the process of volumetric reduction during the loss of water content.

Alexandre et. al (2013) affirmed that among the research carried out by food technology is the search for an increase in the useful life of the food product, in order to convert them into more stable products, with storage for longer periods, using as main techniques the freezing and drying of food. The banana is obtained by natural or artificial drying of the mature fruit, usually from the banana nanica, which has high sugar contents. 
According to Brooker et al. (1992) drying is the simultaneous process of heat and mass transfer, heat transfer from the air to the product and the water content of this to the air. The conservation of food by drying is based on the fact that with the reduction of available water in the products there is a reduction of water activity and the rate of chemical reactions, such as the development of microorganisms (Christensen and Kaufmann, 1974).

Bansal and Garg (1987) recommend that the maximum temperature for drying the banana is $70{ }^{\circ} \mathrm{C}$, the initial water content of the banana is usually around $80 \%$ wet basis (w.b.) and the final one, recommended by the authors, of $15 \%$ (w.b.). Dried bananas are stable to the action of microorganisms if the water content is less than $23 \%$ (w.b.). The use of suitable drying techniques can lead to the obtainment of a product of light color, soft consistency and pleasant taste and aroma (Medina et al., 1978).

The mathematical modeling has been studied by several researchers using different agricultural products and it is therefore of great importance the use of mathematical models to represent the drying processes. In addition to such information, they are valid for the development of equipment with better efficiency and more accurate predictions in drying time (Faria et al., 2012).

Several researches were created with the objective of knowing the drying kinetics of fruits and agricultural products: apple banana (Silva et al., 2009), leaf of aroeira (Goneli et al., 2014); star fruit (Leite et al., 2016); coffee (Siqueira, 2017); quinoa grains (Moscon et al., 2017).

Due to the importance of the physical properties of the agricultural products and their transformations during processing, this work had as objective to evaluate the volumetric contraction of the banana (Musa spp.) during the drying process in order to obtain the dried banana. Besides determine the drying curve and show the rate of water reduction of the banana at three different drying air temperatures.

\section{MATERIAL AND METHODS}

The work was realized at the Technological Center in the Department of Agricultural and
Environmental Engineering and at the Grain Processing and Storage Laboratory of the Fluminense Federal University - Niterói - RJ.

For the work were used bananas nanica (Musa spp.) mature acquired in the local commerce, which were completely yellow, with coffee areas in the stadium of color 7 (Chitarra and Chitarra, 1990), ideal for making dried bananas.

The initial water content was determined gravimetrically, by mass loss in the oven at $105 \pm$ $1{ }^{\circ} \mathrm{C}$ located at the Laboratory of Soil Mechanics of the Federal Fluminense University until constant weight (Instituto Adolfo Lutz, 1985).

To measure the initial volume of the banana, was used volume equations of known geometric shapes that most resembled the banana. Therefore, the banana was divided into 6 parts to find a similar geometric shape and to make the error minimum.

For the banana extremity the volume equation of a semi-ellipsoid (Figure 1a) was used, due to the great similarity. For the central part of the banana, divided into four parts, the equation of the volume of a cone trunk (Figure 1b) was used.

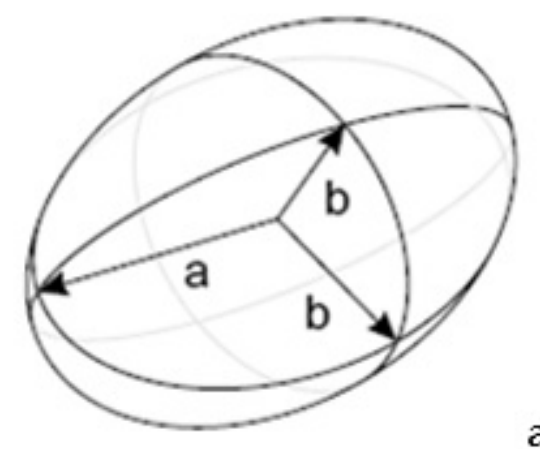

a

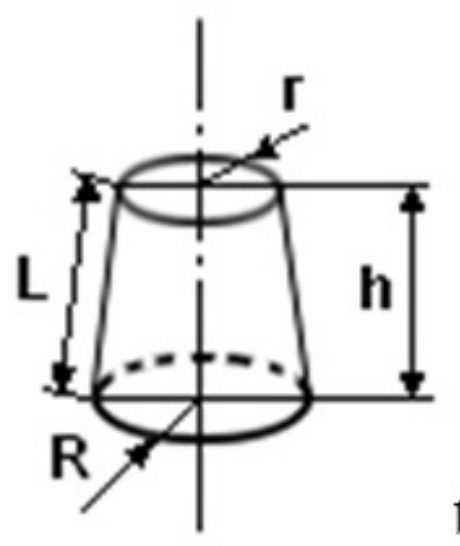

Figure 1: a) Geometric shape of an ellipsoid; b) Geometric shape of a cone trunk. 
According to Forbes (2000), the volume of an ellipsoid is (Equation 1):

$\mathrm{V}=(4 / 3) \pi \mathrm{ab} \mathrm{b}^{2}$

The extremity of the banana resembles a semi-ellipsoid and therefore the equation used to calculate the volume of the banana extremity was (Equation 2):

$\mathrm{V}=(4 / 6) п \mathrm{a}(\mathrm{b} / 2)^{2}$

where,

$\mathrm{a}=$ average height of the banana tip;

$b=$ mean diameter of the banana tip.

The equation for cone trunk volume is (Equation 3):

$\mathrm{V}=\frac{\pi}{12} \mathrm{~h}\left(2 \mathrm{R}^{2}+2 \mathrm{R} \times 2 \mathrm{r}+2 \mathrm{r}^{2}\right)$

where,

$\mathrm{h}=$ average height of a part of the banana;

$\mathrm{R}=$ mean radius of the major base;

$\mathrm{R}=$ mean radius of the minor base.

The diameters and heights of the banana parts were measured with a PANTEC brand digital caliper with scale in millimeters.

In order to assess the results, the volume of each part of the banana was determined from the volume of water displaced by the introduction of the fruits into test tubes of different volumes, according to the size of the parts of the banana described by Machado (1989).

The calculation of the volume using the geometric formulas, as well as the measurement of the volume of each part of the fruit through the volume of displaced water, was carried out in three replications.

Then, the difference between the calculated volume and the measured volume of each part of the fruit was calculated and the differences were added. The error found was less than $5 \%$, which makes it possible to use the geometric formulas to calculate the fruit volume.

The experiment was carried out for three distinct air temperatures usually used for banana drying, 50, 60 and $70{ }^{\circ} \mathrm{C}$ and with average relative humidity of $18.68 ; 11.72$ and $7.64 \%$ respectively for each temperature. The relative humidity was calculated by the GRAPSI program. To measure them, the dry bulb temperature and the wet bulb temperature of the ambient air were recorded at each weighing using mercury thermometers.

The drying process takes place in three stages, in the first, the product is very humid so the water of the more superficial layers are easily removed. In the second stage, the water that lies in the innermost layers migrates to the surface and is then removed. In the third stage, the remaining water is in the interstices of the product and is thus hardly removed, requiring high temperatures.

Very mature bananas were chosen for the experiment. In each drying, 10 bananas were used and the sums of the weights were used for the calculations. The drying took place in the stove with forced air circulation and the product was weighed using a digital scale with precision of two decimal places.

For the adjustment of the mathematical models to the experimental data of humidity ratio, in order to estimate its parameters, a nonlinear regression analysis was performed by the Quasi-Newton method, using the program STATISTICA $5.0^{\circledR}$.

According to bibliographical research based on the latest studies, equations were adopted that best fit the experimental data to express the Ratio of Moisture as a function of temperature and drying time, and also due to its relative precision and generality, as described in Table 1, where the equations 4 to 7 are presented.

Table 1: Mathematical models of reason of humidity used in the work.

\begin{tabular}{ccc}
\hline Model & Equation \\
\hline Exponential & $\mathrm{MR}=\exp (-\mathrm{kt})$ & $(4)$ \\
Page & $\mathrm{MR}=\exp \left(-\mathrm{kt} \mathrm{t}^{\mathrm{a}}\right)$ \\
Thompson & $\mathrm{MR}=\mathrm{A} \ln (\mathrm{MR})+\mathrm{B}(\ln (\mathrm{MR}))^{2}$ \\
Waste modified & $\mathrm{MR}=(\mathrm{a} \exp (-\mathrm{bt})+\mathrm{c} \exp (-\mathrm{dt})) \mathrm{T}^{\mathrm{e}}$
\end{tabular}

The equation for determining the Equilibrium Moisture "(Me)" used for the MR calculation was 
the Modified Halsey equation. This equation was the most suitable for the banana, according to Andrade et al. (2010).

$\mathrm{MR}=\frac{\mathrm{M}-\mathrm{Me}}{\mathrm{Mo}-\mathrm{M}}$

where,

$\mathrm{MR}=$ Moisture Ratio (dimensionless);

$\mathrm{M}=$ Moisture content at time $\mathrm{t}$ (d.b.);

Mo = Initial moisture content (d.b.);

$\mathrm{Me}=$ Equilibrium Moisture (d.b.)

$\mathrm{Me}=\frac{\exp ^{(\mathrm{a}-\mathrm{bT})}}{-\operatorname{In}(\mathrm{aw})^{1 / \mathrm{c}}}$

where,

$\mathrm{t}=$ time $(\mathrm{h})$;

$\mathrm{k}=\mathrm{a} \exp \frac{-\mathrm{b}}{273.15+\mathrm{T}}$;

$\mathrm{T}=$ Drying air temperature $\left({ }^{\circ} \mathrm{C}\right)$;

$\mathrm{A}=-\mathrm{a}+\mathrm{bT}$;

$\mathrm{B}=\mathrm{a} \exp (\mathrm{bT})$;

$\mathrm{Aw}=$ water activity (decimal);

$\mathrm{k}, \mathrm{a}, \mathrm{b}, \mathrm{c}, \mathrm{d}, \mathrm{e}, \mathrm{A}, \mathrm{B}=$ Constants that depend on the product.

The water activity (Aw) was considered to be equal (in decimal) relative humidity, according to Sauer (1992).

In order to select the model that best represented the moisture ratio of the product, the experimental data were compared with the values estimated by each model, by the mean relative error $(\mathrm{P})$ and estimated mean error (SE), equations 10 and 11 . The capacity of the model describe the physical process is inversely proportional to the value of SE (Draper and Smith, 1981, Douglas and Donald, 1988; Chen and Morey, 1989; Chen and Jayas, 1998).

$$
\begin{aligned}
& \mathrm{P}=\frac{100}{\mathrm{n}} \sum \frac{\left|\mathrm{Y}-\mathrm{Y}_{0}\right|}{\mathrm{Y}} \\
& \mathrm{SE}=\sqrt{\sum \frac{\left(\mathrm{Y}-\mathrm{Y}_{0}\right)^{2}}{\mathrm{GLR}}}
\end{aligned}
$$

where,

$\mathrm{Y}=$ experimental value observed;

$Y_{0}=$ value calculated by the model;

GLR = degrees of freedom of the model;

$\mathrm{N}=$ number of experimental observations.

According to Corrêa et al. (2001), the Water Reduction Rate (WRR) can be defined as the amount of water that a product loses per unit of dry matter per unit of time.

$\mathrm{WRR}=\frac{\mathrm{Ma} 0-\mathrm{Mai}}{\mathrm{Ms}(\mathrm{ti}-\mathrm{t} 0)}$

where,

WRR $=$ Water Reduction Rate $(\mathrm{kg}$ water kg dry matter $\left.{ }^{-1} \mathrm{~h}^{-1}\right)$;

$\mathrm{Ma} 0=$ Previous total mass of water $(\mathrm{kg})$;

Mai $=$ Current total mass of water $(\mathrm{kg})$;

Ms $=$ Dry matter $(\mathrm{kg})$;

$\mathrm{t} 0=$ Total previous drying time $(\mathrm{h})$;

$\mathrm{ti}=$ Current total drying time $(\mathrm{h})$.

The data necessary for the study of the volumetric contraction of the banana were obtained during the banana's drying. The bananas used for the calculation of volumetric contraction were distributed in 6 parts to obtain the initial volume and were placed in the oven at temperatures of 50, 60 and $70{ }^{\circ} \mathrm{C}$.

The volumetric contraction of the banana $(\Psi)$ was determined by the relation between the volume for each water content at the time and the initial volume, according to the Equation 13:

$\Psi=\frac{\mathrm{V}-\mathrm{V} 0}{\mathrm{~V} 0}$

The volume of each part of the banana was determined by volume equations of known geometric shapes (Equations 2 and 3).

To the experimental data of volumetric contraction $(\Psi)$ were adjusted the mathematical models Linear modified, Exponential modified, Bala and Woods modified, Rahman modified and Corrêa et al modfied, as follows in Table 2 (Equations from 14 to 18 ): 
Table 2: Mathematical models of Volumetric Contraction used in the work.

\begin{tabular}{ccc}
\hline Model & Equation \\
\hline Linear modified & $\Psi=\mathrm{a}(+(\mathrm{bU})) \mathrm{T}^{\mathrm{c}}$ & $(14)$ \\
$\begin{array}{c}\text { Modified Exponential } \\
\text { BALA \& WOODS } \\
\text { modified }\end{array}$ & $\Psi=\mathrm{a}\left(\exp \left(\mathrm{bU}\left(\mathrm{T}^{\mathrm{c}}\right)\right)\right)$ & $(15)$ \\
$\begin{array}{c}\text { RAHMAN modified } \\
\text { CORREA et al } \\
\text { modified }\end{array}$ & $\Psi=\left(1+\left(\mathrm{a}\left(1-\exp \left(-\mathrm{b}\left(\mathrm{U}_{0}-\mathrm{U}-\mathrm{U}_{0}\right)\right)\right)\right)\right) \mathrm{T}^{\mathrm{b}}$ \\
\hline
\end{tabular}

where,

$\Psi=$ Volumetric contraction index (decimal);

$\mathrm{U}=$ Moisture content (d.b.);

$\mathrm{U} 0$ = Initial moisture content (d.b.);

$\mathrm{T}=$ Drying air temperature $\left({ }^{\circ} \mathrm{C}\right)$;

$\mathrm{a}, \mathrm{b}, \mathrm{c}=$ Constants that depend on the product.

For the adjustment of the models to the experimental data, the STATISTICA $5.0^{\circledR}$ program was used. Non-linear regression analysis was performed using the Quasi-Newton method. The experimental data were compared with the values calculated by the models, by average error relative $(\mathrm{P})$ and estimated (SE) average errors, according to equations 10 and 11 previously described.

\section{RESULTS AND DISCUSSION}

Figure 2 shows the experimental drying values for the banana submitted to drying air temperatures of 70,60 and $50^{\circ} \mathrm{C}$.
It is possible to notice that with the increase of drying air temperatures, a higher water removal rate of the product occurred, which is equivalent to the result of drying kinetic studies for other products. Such as coffee (Alves et al., 2013), red rice (Santos and Oliveira, 2013), fig (Corrêa et al., 2015), garlic (Cagnin et al., 2017), quinoa (Moscon et al., 2017), bean (Quequeto et al., 2017). The time used for drying for the three temperatures was over 20 hours. For the temperature of $70^{\circ} \mathrm{C}$ the drying time was of 20 hours and 40 minutes. At $60^{\circ} \mathrm{C}$ the time was 27 hours and 30 minutes and for the temperature of $50^{\circ} \mathrm{C}$ the drying took 32 hours.

It is observed that the drying of the dried banana occurs in the period of decreasing drying rate, demonstrating that there is difficulty in the transfer of heat and mass from the interior of the product to the surface, so that diffusion is the main mechanism in the water movement during drying (Kashaninejad et al., 2007).

With the experimental values obtained with the 3 temperatures and 3 relative humidity, the drying curve for the banana was obtained by non-linear regression.

The Table 3 presents the moisture content data (MR) of the banana-pass obtained experimentally through equation (08) for the temperatures of 50,60 and $70{ }^{\circ} \mathrm{C}$, the initial moisture, the equilibrium moisture obtained through equation (09) and the WRR obtained by equation (12).

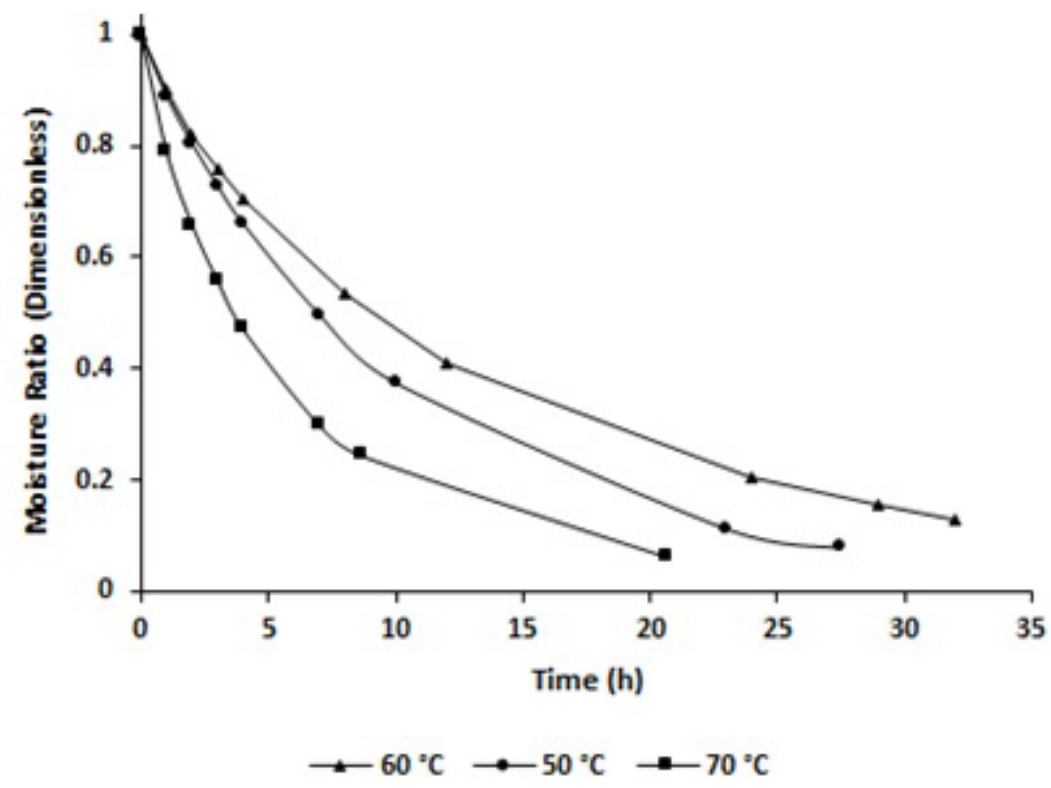

Figure 2: Variation of the Moisture Ratio at drying air temperatures of 70,60 and $50^{\circ} \mathrm{C}$. 
Table 3: Table with equilibrium moisture data, experimental data of moisture ratio and water reduction rate.

\begin{tabular}{|c|c|c|c|c|}
\hline \multicolumn{5}{|c|}{$\mathrm{T}=70^{\circ} \mathrm{C}$} \\
\hline $\mathrm{t}(\mathrm{h})$ & $\mathrm{a}_{\mathrm{w} \text { (decimal) }}$ & $\operatorname{Me}($ d.b. $)$ & MR & $\begin{array}{c}\text { WRR } \\
\left(\mathrm{kg} \mathrm{kg}^{-1} \mathrm{~h}^{-1}\right)\end{array}$ \\
\hline 0 & 0.081 & \multirow{9}{*}{0.06508381} & 1.000 & - \\
\hline 1 & 0.072 & & 0.78844 & 0.6624059 \\
\hline 2 & 0.072 & & 0.65780 & 0.4090341 \\
\hline 3 & 0.072 & & 0.55730 & 0.3146873 \\
\hline 4 & 0.072 & & 0.47052 & 0.2717005 \\
\hline 7 & 0.081 & & 0.29761 & 0.1804743 \\
\hline 8.67 & 0.081 & & 0.24301 & 0.1023703 \\
\hline 20.67 & 0.081 & & 0.06086 & 0.0475251 \\
\hline mean & 0.0764 & & & \\
\hline \multicolumn{5}{|c|}{$\mathrm{T}=60^{\circ} \mathrm{C}$} \\
\hline 0 & 0.1148 & \multirow{10}{*}{0.08020462} & 1.000 & - \\
\hline 1 & 0.1148 & & 0.8898 & 0.4092097 \\
\hline 2 & 0.1148 & & 0.8044 & 0.3167213 \\
\hline 3 & 0.1148 & & 0.7284 & 0.2823722 \\
\hline 4 & 0.1148 & & 0.6610 & 0.2499947 \\
\hline 7 & 0.1220 & & 0.4972 & 0.2026479 \\
\hline 10 & 0.1220 & & 0.3744 & 0.1519713 \\
\hline 23 & 0.1148 & & 0.1120 & 0.0749094 \\
\hline 27.5 & 0.1220 & & 0.0779 & 0.0281569 \\
\hline mean & 0.1172 & & & \\
\hline \multicolumn{5}{|c|}{$\mathrm{T}=50^{\circ} \mathrm{C}$} \\
\hline 0 & 0.1779 & \multirow{11}{*}{0.10212197} & 1.000 & - \\
\hline 1 & 0.1779 & & 0.9006 & 0.268996662 \\
\hline 2 & 0.1890 & & 0.8224 & 0.211547281 \\
\hline 3 & 0.1890 & & 0.7595 & 0.169923924 \\
\hline 4 & 0.1890 & & 0.7046 & 0.148700586 \\
\hline 8 & 0.1890 & & 0.5370 & 0.113343603 \\
\hline 12 & 0.1890 & & 0.4080 & 0.087237525 \\
\hline 24 & 0.1779 & & 0.2043 & 0.045907666 \\
\hline 29 & 0.1890 & & 0.1567 & 0.025742445 \\
\hline 32 & 0.2007 & & 0.1294 & 0.024638588 \\
\hline mean & 0.1868 & & & \\
\hline
\end{tabular}

In order to have a better evaluation of the nonlinear models it is necessary the joint analysis of several statistical parameters, such as standard deviation of the estimate (SE), coefficient of determination (R2) and relative mean error $(\mathrm{P})$.

According to Kashaninejad et al. (2007), the values of the relative mean error $(\mathrm{P})$ represent the deviation of the values observed in relation to the curve estimated by the model to be adjusted. In accordance, Mohapatra and Rao (2005) argue that models that have a relative mean error above $10 \%$ do not adequately describe a phenomenon.

According to Siqueira et al. (2012), the standard deviation of the estimate (SE) expresses how a model accurately describes a particular physical phenomenon, so that the smaller its value, the more appropriate is the fit of the model in relation to the experimental data.

The results of the estimates of the parameters of the Moisture Ratio models tested for the banana and their respective determination coefficients (R2), relative and estimated mean errors are presented in Table 4.

Table 4: Estimates of parameters of the Moisture Ratio model for the dried banana, with their respective determination coefficients (R2), relative $(\mathrm{P})$ and estimated (SE) errors.

\begin{tabular}{ccccc}
\hline $\begin{array}{c}\text { Modelo } \\
\text { Exponencial }\end{array}$ & Parâmetros & $\mathrm{R}^{2}(\%)$ & $\mathrm{P}(\%)$ & $\mathrm{SE}$ (decimal) \\
\hline $70^{\circ} \mathrm{C}$ & $\mathrm{K}=0.1840$ & 98.9328 & 5.6700 & 0.0757 \\
$60^{\circ} \mathrm{C}$ & $\mathrm{K}=0.1002$ & 99.8799 & 4.2331 & 0.0728 \\
$50^{\circ} \mathrm{C}$ & $\mathrm{K}=0.0742$ & 98.9337 & 9.3579 & 0.1362 \\
\hline
\end{tabular}

From the analysis of the results of the Banana Moisture Ratio, it was observed that among the four mathematical models tested, the Exponential model, with data presented in Table 3, presented coefficient of determination above $99.88 \%$. The best values were for the temperature of $60{ }^{\circ} \mathrm{C}$, which presented the coefficient of determination of $99.88 \%$ and relative mean error of $4.23 \%$. The modified waste model also presented adequate results, with a coefficient of determination above $95 \%$.

With the experimental values obtained with the 3 temperatures and 3 relative humidity, the volumetric contraction curve was obtained by non-linear regression. The volumetric contraction data $(\Psi)$ of the banana obtained experimentally through equation (13) for the temperatures of 50, 60 and $70{ }^{\circ} \mathrm{C}$. The initial water content (Uo) was determined gravimetrically, by oven weight loss at $105 \pm 1{ }^{\circ} \mathrm{C}$ (Adolfo Lutz Institute, 1985) and water content after drying (U), determined by Equation 19:

$\mathrm{U}=\frac{\mathrm{Wwater}}{\mathrm{Wdm}}$ 
where,

$\mathrm{U}=$ Water content;

Wwater: Weight of banana water after a certain drying time

Wdm: Weight of dry matter, calculated by equation: Pms = Pbanana - (Uo * Pbanana) are shown in Table 5.

Table 5: Table of volumetric contraction data obtained experimentally.

\begin{tabular}{cccc}
\hline \multicolumn{5}{c}{$\mathrm{T}=70^{\circ} \mathrm{C}$} \\
\hline $\mathrm{t}(\mathrm{h})$ & $\mathrm{V}\left(\mathrm{m}^{3}\right)$ & $\mathrm{U}(\mathrm{d} . \mathrm{b})$. & $\Psi$ \\
0 & 0.0002091 & 3.196 & - \\
4 & 0.0001142 & 1.538 & 0.454 \\
8.67 & 0.0000926 & 0.826 & 0.557 \\
20.67 & 0.0000684 & 0.256 & 0.673 \\
\hline \multicolumn{5}{c}{$\mathrm{T}=60^{\circ} \mathrm{C}$} \\
\hline 0 & 0.0003273 & 3.792 & - \\
4 & 0.0002092 & 2.534 & 0.361 \\
10 & 0.0001519 & 1.470 & 0.536 \\
23 & 0.0001137 & 0.496 & 0,653 \\
27.5 & 0.0001068 & 0.369 & 0.674 \\
\hline \multicolumn{5}{c}{$\mathrm{T}=50{ }^{\circ} \mathrm{C}$} \\
\hline 0 & 0.0002312 & 2.807 & - \\
4 & 0.0001577 & 2.008 & 0.318 \\
12 & 0.0001156 & 1.206 & 0.500 \\
24 & 0.0000991 & 0.655 & 0.571 \\
32 & 0.0000889 & 0.452 & 0.616 \\
\hline
\end{tabular}

The best results of the parameter estimates of the Volumetric Contraction models tested for the banana and their respective determination coefficients, relative and estimated mean errors are presented in Table 6 .

By analyzing the results of the Volumetric Contraction of the banana presented, it was observed that among the five mathematical models tested, the modified Bala and Wood model was the one that presented the determination coefficient of $99.14 \%$ and a relative mean error of $1.67 \%$ for a temperature of $60^{\circ} \mathrm{C}$.

This satisfactory result can be considered due to the already included error of $5 \%$ for the calculation of the Banana Volume through Equations 2 and 3.

According to Corrêa et al. (2006), observed that the modified Bala and Woods (1984) model was the only one that represented the volumetric shrinkage of wheat grains during drying. Still according to Goneli et al. (2011) recommend that only the modified Bala and Woods (1984) models and the Polynomial second degree model can be recommended to predict the phenomenon of volumetric contraction of castor fruit mass.

Table 6: Estimates of the Volumetric Contraction model parameters for the banana, with their respective determination coefficients $\left(R^{2}\right)$ relative $(\mathrm{P})$ and estimated (SE) errors.

\begin{tabular}{ccccc}
\hline $\begin{array}{c}\text { Models: BALA E } \\
\text { WOOD modificado }\end{array}$ & Parameter & $\mathrm{R}^{2}(\%)$ & $\mathrm{P}(\%)$ & $\begin{array}{c}\mathrm{SE} \\
\text { (decimal) }\end{array}$ \\
\hline & $\mathrm{a}=5.2738$ & & & \\
$70^{\circ} \mathrm{C}$ & $\mathrm{b}=0.0004$ & 93.3480 & 3.7030 & 0.0400 \\
& $\mathrm{c}=0.1909$ & & & \\
$60^{\circ} \mathrm{C}$ & $\mathrm{a}=1.1114$ & & & \\
& $\mathrm{~b}=0.5066$ & 99.1410 & 1.6740 & 0.0190 \\
& $\mathrm{c}=0.2502$ & & & \\
$50^{\circ} \mathrm{C}$ & $\mathrm{a}=1.0595$ & & & \\
& $\mathrm{~b}=0.9269$ & 99.7470 & 0.8990 & 0.0100 \\
& $\mathrm{c}=0.2922$ & & & \\
\hline
\end{tabular}

Among the mathematical models, the one that presented smaller values of estimated and relative average errors and greater coefficient of determination was the Exponential for the reason of humidity and for the volumetric contraction was the Bala and Wood modified, being thus indicated to represent these phenomena.

The curves of drying, experimental and simulated by the Exponential model, of the banana for the temperatures of 70,60 and $50{ }^{\circ} \mathrm{C}$, as well as the Water Reduction Rate (WRR) for the same temperatures are shown below (Figures 3, 4 and 5).

It can be seen in Figures 3, 4 and 5 that the WRR for the first hours is large. This is due to the ease that the drying air has to remove the free water from the banana. With the passage of time, the WRR decreases, as well as the amount of free water available in the fruit.

Regarding the drying curves, it can be noted that the difference of the MR in the beginning of the process for the temperatures of 50,60 and $70^{\circ} \mathrm{C}$ is not very high, but increases with the drying time.

At the beginning of the process the differences are smaller because a significant part of the water content is free on the surface of the banana and in this way it is easily removed. For the remaining drying times, the differences increase due to the internal resistance to water content transport. 


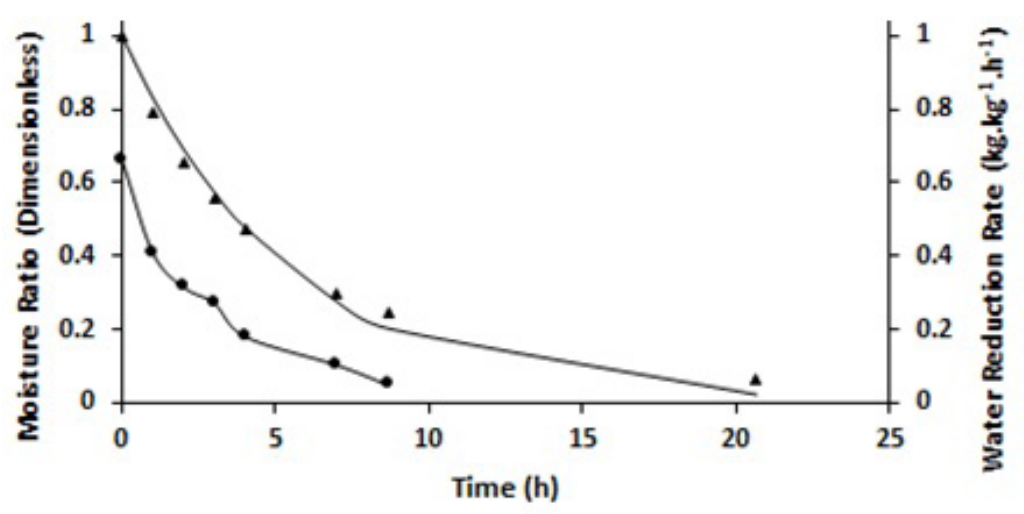

- MR (Experimental) - —Water Reduction Rate - (MR) Simulated

Figure 3: Experimental and simulated values for the Exponential model (04) of the Water Ratio and Water Reduction Rate of the banana as a function of the drying time, for a temperature of $70^{\circ} \mathrm{C}$.

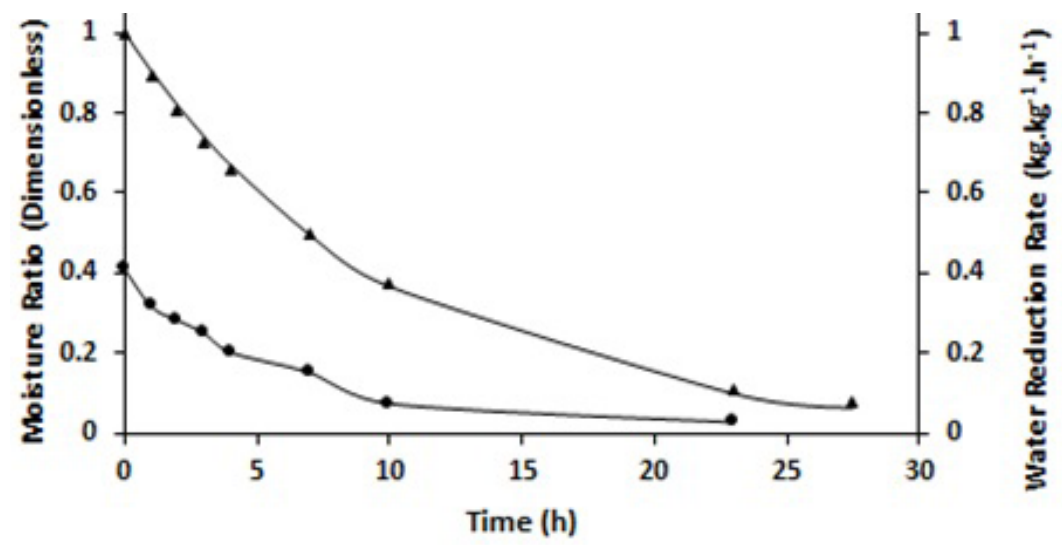

\section{- MR (Experimental) $\rightarrow$ Water Reduction Rate $\longrightarrow$ MR (Simulated)}

Figure 4: Experimental and simulated values for the Exponential model (04) of the Moisture Ratio and Water Reduction Rate of the banana as a function of the drying time, for a temperature of $60^{\circ} \mathrm{C}$.

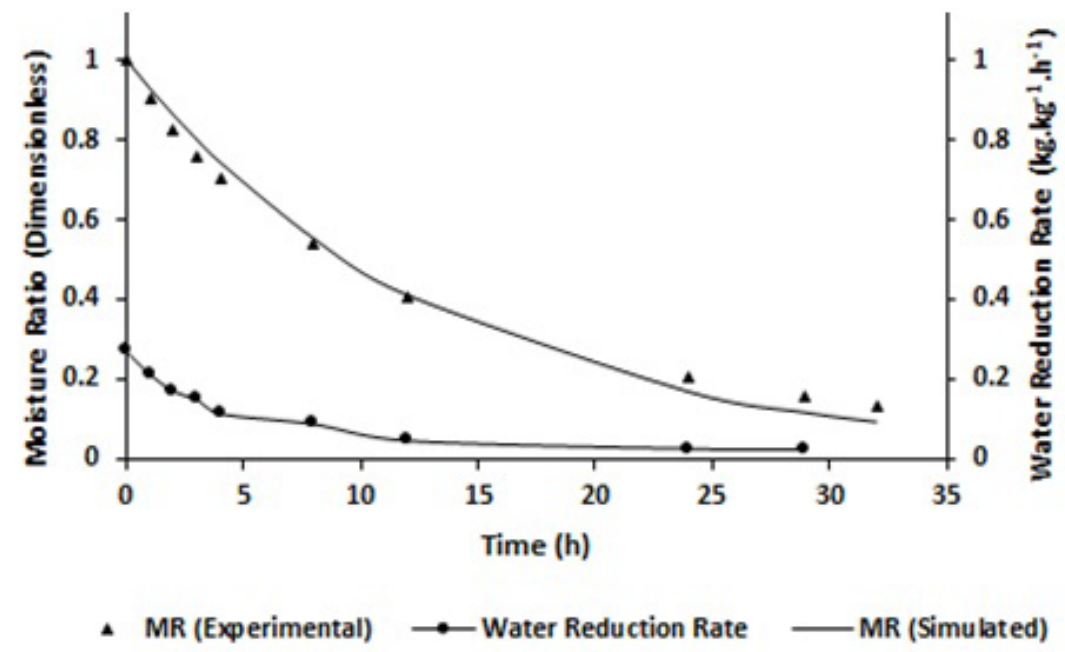

Figure 5: Experimental and simulated values for the Exponential model (04) of the Moisture Ratio and Water Reduction Rate of the banana as a function of the drying time, for a temperature of $50{ }^{\circ} \mathrm{C}$.

Figure 6 shows the graph for the for the drying air temperatures of 50,60 and Volumetric Contraction curves versus time $70^{\circ} \mathrm{C}$ : 


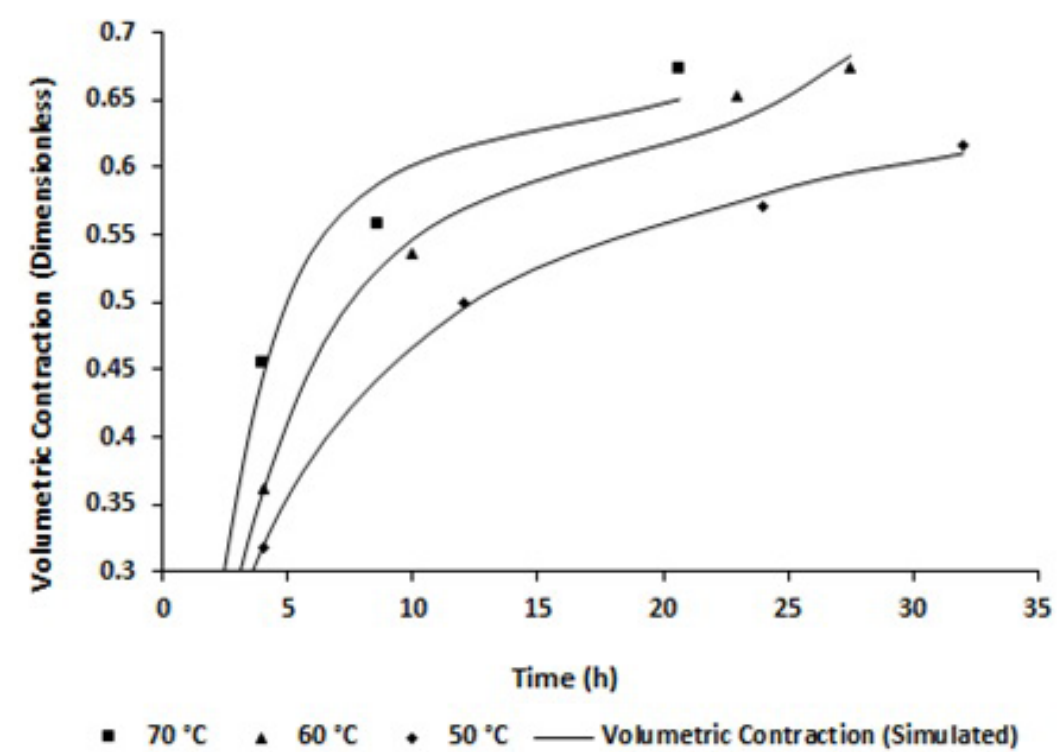

Figure 6: Values collected in the experiment and simulated by the Bala and Wood modified model (16) of the Volumetric Contraction of the banana as a function of the drying time, for different temperatures.

It is observed in Figure 6 that for higher drying temperatures, the greater the volumetric contraction of the banana. And also, that at the beginning of the drying process, the volumetric contraction is more pronounced and decreasing with the passage of time.

\section{CONCLUSIONS}

According to the conditions that the present work was developed, was conclude that: among the models tested, the one that best fit the results in the prediction of the Moisture Ratio was the Exponential model, and for the Volumetric Contraction was the modified Bala and Wood model.

The Water Reduction Rate (WRR) is great for the first few hours of drying due to the large amount of free water in the product.

Volumetric shrinkage is higher at higher temperatures.

The Volumetric Shrinkage is more intense for the first few hours of drying.

\section{ACKNOWLEDGEMENTS}

CAPES, , Thermo-science Laboratory at UFF and PPGEA (Agricultural Engineering Graduate Program at UFLA) supported this research project and PPGEA (Agricultural Engineering Graduate Program at UFLA) supported this research project.

\section{REFERENCES}

ALEXANDRE, H. V.; SILVA, F. L.; GOMES, J.; SILVA, O.; CARVALHO, J.; LIMA, E. Cinética de secagem do resíduo de abacaxi enriquecido. Revista Brasileira de Engenharia Agrícola e Ambiental, 17(6):640-646, 2013.

ALVES, G. E.; et at. cinética de secagem de café natural para diferentes temperaturas e baixa umidade relativa. Coffee Science, 8 (2):238-247, 2013.

ANDRADE, T. DE et al. Equilíbrio higroscópico e entalpia de vaporização da banana-passa e da casca da banana. Revista Brasileira de Armazenamento, 35:80- 89, 2010.

BANSAL, N. K., GARG, H. P. Solar crop drying. In: A. S. Mujumdar (ed.). Advances in drying. New York: Hemisphere Publishing Corporation, 1987. Chapter 6: v. 4, p. 293-294.

BALA, B. K.; WOODS, J. L. Simulation of deep bed malt drying. Journal Agricultural Engineering Research, 30(3):235-244, 1984.

BROOKER, D. B.; BAKKER-ARKEMA, F. W.; HALL, C. W. Drying and storage of grains and oilseeds. Westport: The AVI Publishing Company, 1992. 
CAGNIN, C. et al. Alho: cinética de secagem e propriedades termodinâmicas. Bioscience Journal, 33(4):905-913, 2017.

CHEN, C.; JAYAS, D.S. Evaluation of the GAB equation for the isotherms of agricultural products. Transactions of ASAE, 41(6):1755-1760, 1998.

CHEN, C.; MOREY, V. Equilibrium relativity humidity (ERH) relationships for yellow-dente corn. Transactions of ASAE, 32(3):999-1006, 1989.

CHITARRA, M. I. F.; CHITARRA, A.B. Pós-colheita de frutos e hortaliças: fisiologia e manuseio. Lavras: ESAL/FAEPE, 1990. 320p.

CHRISTENSEN, C. M.; KAUFMANN, H. H. Microflora. In: CHRISTENSEN, C. M. Storage of cereal grain and their products. St. Paul, MN: American Association of Cereals Chemists, 1974. p.158-192.

CORRÊA, L. C. et al. Cinética de secagem, contração volumétrica e análise da difusão líquida do fgo (Ficus carica L.). Revista Brasileira de Engenharia Agrícola e Ambiental, 19(8):797-802, 2015.

CORREAA, P. C; MACHADO, P. F; ANDRADE, E. T. Cinética de secagem e qualidade de grãos de milhopipoca. Lavras, 2001.

CORRÊA, P. C. et al. Determinação e modelagem das propriedades físicas e da contração volumétrica do trigo, durante a secagem. Revista Brasileira de Engenharia Agrícola e Ambiental, 10(3):665-670, 2006.

DEFARIA, R.Q. etal. Cinética de secagem de sementes de crambe. Revista Brasileira de Engenharia Agrícola e Ambiental, 16(5):573-584, 2012.

DE LIMA, A. G. B; NEBRA, S. A.; QUEIROZ, M.R. Comunicado Técnico Aspectos Científico E Tecnológico Da Banana. Revista Brasileira de Produtos Agroindustriais, 2(1):87-101, 2000.

DOUGLAS, M.; DONALD, G.W. Non linear regression analysis and its applications. New York: Weley series in probability and mathematical statistics, John Wiley \& Sons., 1988. 365p.

DRAPER, N.R.; SMITH, H. Applied regression analysis. New York: Weley series in probability and mathematical statistics, John Wiley \& Sons, 1981.709p.
FORBES, K. Volume Estimation of Fruit from Digital Profile Images. Cape Town: University of Cape Town, 2000.

GONELI, A. L. D. et al. Contração volumétrica e forma dos frutos de mamona durante a secagem. Acta Scientiarum. Agronomy, 33(1):1-8, 2011.

GONELI, A. L. D. et al. Modelagem matemática e difusividade efetiva de folhas de aroeira durante a secagem. Pesquisa Agropecuária Tropical, 44(1):5664, 2014.

INSTITUTO ADOLF LUTZ. Normas Analíticas do Instituto Adolf Lutz. 3ed., São Paulo, p.21-7, 1985.

KASHANINEJAD, M. et al. Thin-Iayer drying characteristics and modeling of pistachio nuts. Journal of Food Engineering, 78(1):98-108, 2007.

LEITE, D. D. F. et al. Avaliação da cinética de secagem da carambola em secador convectivo. Revista Verde de Agroecologia e Desenvolvimento Sustentável, 11(2):01-04, 2016.

MACHADO, R. C. R; ALMEIDA, H. A. Estimativa do volume do fruto do cacau. Revista Brasileira de Fisiologia Vegetal. 1, 1989.

MEDINA, J. C. ET AL. Banana: da cultura ao processamento e comercialização. 3ed. Campinas (SP), ITAL, 1978. 197p.

MOHAPATRA, D.; RAO, P.S. A thin layer drying model of parboiled wheat. Journal of Food Engineering. p.513-518, 2005.

MOSCON, E. S. et al. Cinética de secagem de grãos de quinoa (chenopodium quinoa w.). Revista Engenharia na Agricultura, 25(04):318-328, 2017.

QUEQUETO, W. D. et al. Cinética de secagem dos grãos de feijão cultivar ipr tangará. Energia na Agricultura, 32(4):408-415, 2017.

RIBEIRO, T. D. R. W. Descrição da cinética de secagem de frutos de banana Prata e D'Água por modelos de regressão não linear. Revista da estatística, 3, 2014.

SANTOS, D. DA C.; de OLIVEIRA, E. N. A. Cinética de secagem de grãos de arroz-vermelho. Revista Acadêmica: Ciências Agrárias e Ambientais, 11(2):35-43, 2013. 
SAUER, D. B. Storage of Cereal Grains and Their Products. 4.ed. American Association of Cerial Inc, 1992. 615p.

SILVA, A. S. et al. Cinética de secagem em camada fina da banana-maçã em secador de leito fixo. Revista Brasileira de Produtos Agroindustriais,11(2):129-136, 2009.

SIQUEIRA, V. C.; RESENDE, O.; CHAVES, T. H. Determination of the volumetric shrinkage in jatropha seeds during drying. Acta Scientiarum. Agronomy, 34(3):231-238, 2012.

SIQUEIRA, V. C. et al. Cinética de secagem de café natural beneficiado com alto teor de água. Coffee Science, 12(3):400-409, 2017. 